\title{
Diabetes in Pregnancy: Islet Cell Proliferation in the Fetal Rat Pancreas
}

\author{
I. Swenne and U. Eriksson \\ Department of Medical Cell Biology, University of Uppsala, Uppsala, Sweden
}

\begin{abstract}
Summary. Since it has not been possible to reproduce, in the rat, the hyperplasia of the islets of Langerhans observed in the fetus in human diabetic pregnancy, the rate of proliferation of the endocrine pancreas of fetuses of manifest diabetic rats has been studied.

Rats were rendered diabetic by streptozotocin injections before mating. At days 20 or 22 of gestation the pregnant rats were injected with colchicine and sacrificed at 1-h intervals. The mitotic indices of the fetal endocrine pancreas were determined and plotted against the time after colchicine injection. The production of new cells (i.e. the cell birth rate) was estimated from the slopes of the regression lines.
\end{abstract}

On both days 20 and 22 of gestation, the cell birth rates of the endocrine pancreas of the fetuses of manifest diabetic mothers were only one-third of the control values obtained in normal, age-matched fetal pancreas (daily cell birth rate $=$ $10 \%$ ). This finding corresponds to the previous observation of a low $B$ cell mass in the offspring of diabetic rats.

The results indicate that the growth and development of the fetal endocrine pancreas is retarded in manifest diabetic pregnancy in the rat.

Key words: Diabetes, rat pregnancy, islets of Langerhans, B cell proliferation, diabetic fetopathy.
In human diabetic pregnancy, pancreatic islet hyperplasia, hyperinsulinaemia and macrosomia are common features of the fetus and the neonate $[1,2]$. Attempts to investigate this phenomenon experimentally have led to controversy as to whether the islet hyperplasia and other signs of diabetic fetopathy can be mimicked in the offspring of rats experimentally induced with diabetes [3-8]. In a recent morphometric study in the rat, a reduced rather than a hyperplastic B cell mass was observed in the fetuses and neonates of manifest diabetic rats [9]. In addition, these animals showed both a lowered pancreatic insulin content [10] and a decreased rate of insulin biosynthesis [11]. These data were interpreted to indicate a delayed growth and development of the endocrine pancreas of the offspring of diabetic rat mothers $[9,12]$. In the present study, a stathmokinetic technique has been applied in vivo to fetal rats. This method yields a direct measure of pancreatic islet cell division by estimating the accumulation of mitotic figures after a colchicine injection. Such an approach should help to clarify, in more detail, the effect of maternal diabetes on the growth of the fetal B cell. Furthermore, this approach would indicate the extent to which mitotic division contributes to the rapid increase in the fetal $\mathrm{B}$ cell mass during late pregnancy in the rat $[9,13]$.

\section{Material and Methods}

\begin{abstract}
Animals
Virgin Sprague-Dawley rats (Anticimex, Sollentuna, Sweden), body weight $250 \mathrm{~g}$, were given a single IV injection of streptozotocin (SZ; kindly donated by Dr W. Dulin, Upjohn, Kalamazoo, USA) at a dose of $40-50 \mathrm{mg} / \mathrm{kg}$ body weight. Rats with a serum glucose concentration $>20 \mathrm{mmol} / \mathrm{l} 1$ week after $\mathrm{SZ}$ administration were classified as manifest diabetic [12]. Control animals did not receive any injections. Two weeks after the SZ injection, the animals were caged overnight with male rats three times weekly and vaginal smears were taken on the following morning. The day on which a sperm-containing smear was found was considered as day 0 of pregnancy.
\end{abstract}

\section{Stathmokinetic Experiments}

Normal and manifest diabetic pregnant rats were used for stathmokinetic experiments on gestational days 20 and 22. Colchicine (Apoteksbolaget, Stockholm, Sweden) at a dose of $2.5 \mathrm{mg} / \mathrm{kg}$ maternal body weight, was injected IV into the pregnant rats between 10.00 and $14.00 \mathrm{~h}$. The serum glucose concentrations of the diabetic rats were determined on the day of the experiment. The animals were killed by cervical dislocation $1,2,3$ or $4 \mathrm{~h}$ after the injection and the fetuses were rapidly removed through a midline incision. The fetal pancreatic glands were quickly dissected free of the surrounding tissue and fixed in Bouin's solution. In the control group, four fetuses were collected from each litter and in the diabetic group up to eight fetuses were taken from each rat. For each time point calculated for the different 


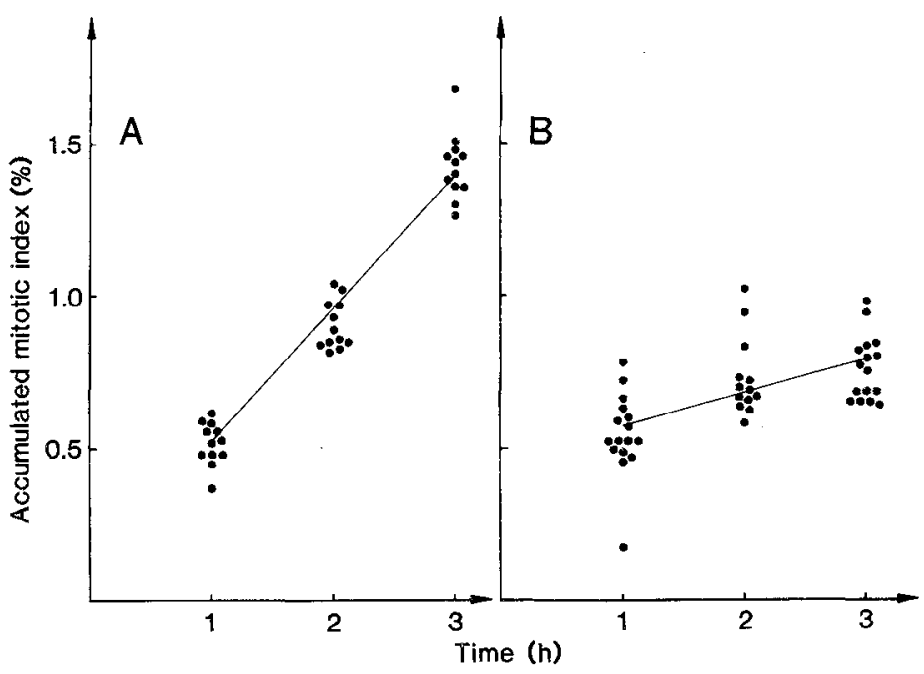

Fig. $1 \mathrm{~A}$ and B. Accumulated mitotic indices in the islets of Langerhans of fetuses of normal $\mathbf{A}$ and manifest diabetic $\mathbf{B}$ rats at day 20 of gestation. The pregnant rats were injected IV with colchicine and fetal pancreatic specimens were removed from the mothers which were sacrificed at $1 \mathrm{~h}$ intervals. The accumulated mitotic indices of the endocrine pancreas of the fetuses were determined in sections stained with haematoxylin and eosin and expressed as a percentage of the total number of islet cells scored. The mitotic indices of the individual fetuses are indicated in the figures together with fitted least square regression lines. The values of the slopes of the lines \pm SEM are shown in Table 1

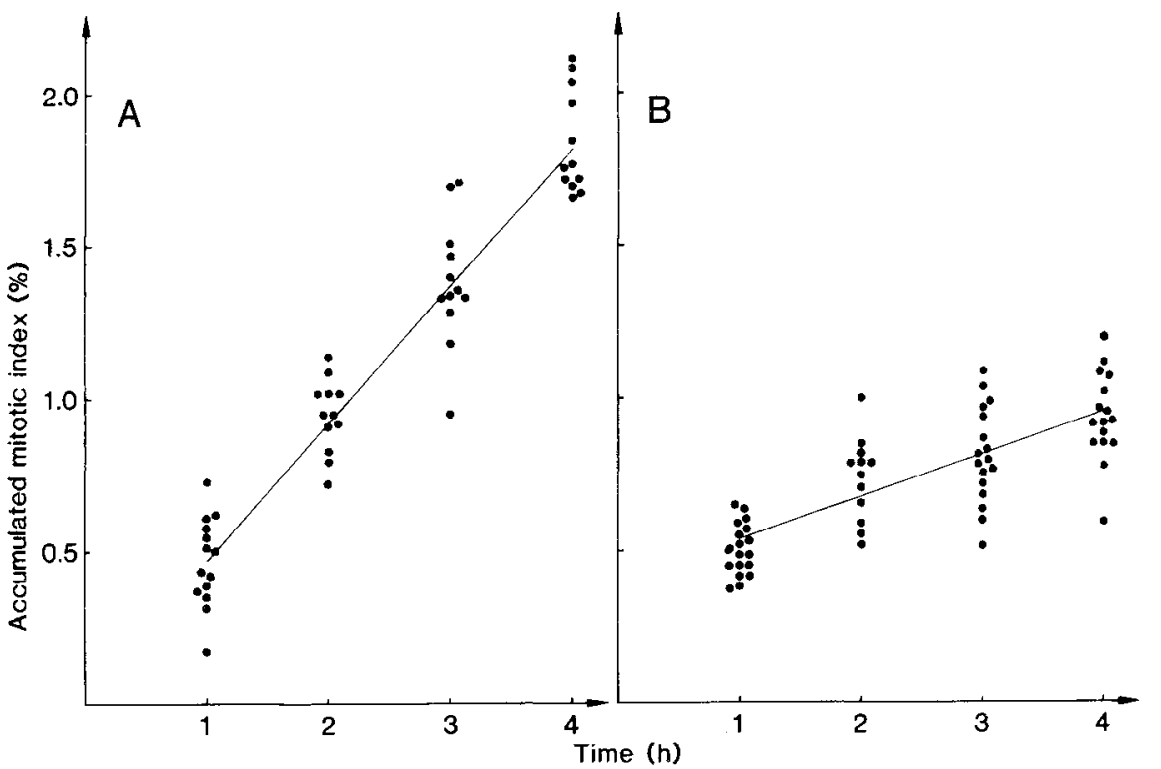

Fig. $2 \mathrm{~A}$ and B. Accumulated mitotic indices in the islets of Langerhans of fetuses of normal A and manifest diabetic $\mathbf{B}$ rats on day 22 of gestation. Experimental details are given in the legend to Figure 1. The values of the slopes of the lines \pm SEM are shown in Table 1 experimental groups, at least 12 glands from the fetuses of two to four pregnant rats were collected. In addition, a specimen of the small intestine of the pregnant rat and of each fetus were similarly fixed in Bouin's solution.

To determine the optimal dosage of colchicine, IV injections of the drug were given on day 22 of pregnancy to both normal and diabetic pregnant rats in doses ranging from $0.625-5.0 \mathrm{mg} / \mathrm{kg}$ body weight. The fetal pancreases were removed 2 or $3 \mathrm{~h}$ after the injection. At a dose of $5.0 \mathrm{mg} / \mathrm{kg}$, all fetuses were found to be dead when the uterus was sectioned. The accumulation of mitotic figures in the fetal endocrine pancreas was higher if the mother had received $2.5 \mathrm{mg} / \mathrm{kg}$ rather than $1.25 \mathrm{mg} / \mathrm{kg}$ of colchicine. Furthermore, 'anaphase escape' (i. e. cells completing mitosis) was observed in the fetal islets following the $1.25 \mathrm{mg} / \mathrm{kg}$ colchicine treatment. The dose of colchicine used throughout the study was therefore established as $2.5 \mathrm{mg} / \mathrm{kg}$ body weight.

\section{Morphometry and Statistics}

The fixed fetal pancreatic glands were dehydrated, embedded in paraffin and each gland was cut, in entirety, into $7 \mu \mathrm{m}$ thick serial sections. The first five sections in each series were placed on the same glass slide, the next 45 sections discarded, the next five sections placed on a single slide and this regimen repeated, resulting in a total of 5-12 slides per pancreas, which were subsequently stained with hacmatoxylin and eosin and mounted. To estimate the accumulation of mi- totic figures, one section was chosen by random numbers from each pancreas. The islets were identified by scanning the sections at a low magnification ( $x$ 125). Using an oil immersion lens (final magnification $\times 1250$ ) the number of mitotic figures accumulated in the islets of each section were counted and expressed as a percentage of the total number of islet cells scored. If the total number of islet cells scored in a single section was $<1000$ another section of the same pancreas was chosen at random and counted in the same way. All the observations were performed by one person.

To estimate the cell birth rate (i.e. the fraction of new cells produced per unit time) the mitotic indices of the individual fetuses were used to construct least square regression lines of mitotic indices versus time after colchicine injection. The slopes of the regression lines were compared using Student's t-test for unpaired observations.

\section{Results}

At day 20 of gestation most fetuses were dead $4 \mathrm{~h}$ after the colchicine injection in both the normal and manifest diabetic groups. However, $3 \mathrm{~h}$ after injection fetal viability appeared normal and pancreatic glands were therefore collected up to this time point.

Numerous mitotic figures arrested by colchicine were readily identified in the intestinal mucosa of both 
the normal and manifest diabetic pregnant rats and were taken as an indication of successful drug injection. In these animals, mitotic figures were found also in the gut mucosa of the fetuses confirming placental transfer of colchicine.

The pancreatic morphology of the colchicine-treated animals was well preserved, but in the fetuses of the manifest diabetic groups the islets were smaller and the exocrine parenchyma less well organized into acini compared with the normal fetuses. The islets could nevertheless be identified and delineated from the surrounding tissue. Since haematoxylin-eosin stained islet cells have a clear cytoplasm and round interphase nuclei compared with the acinar cells, the colchicine arrested mitotic figures could be distinctly identified. These arrested cells had a lighter cytoplasm than the interphase cells and the chromosomes appeared irregularly arranged or condensed into a dark network.

When the accumulated mitotic indices of the individual fetuses were plotted against time and used to construct least square regression lines (Fig. $1 \mathrm{~A}$ and B; Fig. 2A and B) a high degree of correlation was observed in all groups $(p<0.001)$. The slopes of all four regression lines differed from zero (normal groups: $p<$ 0.001 ; manifest diabetic groups: $p<0.05$ ) indicating a significant accumulation of mitotic figures with time. The cell birth rates from fetuses of normal rat mothers were similar at days 20 and 22 of gestation as evidenced by the near parallel slopes of the respective regression lines (Table 1). In both the manifest diabetic groups the endocrine pancreatic cell birth rates were reduced to $25-30 \%$ of those of the corresponding control groups. Since the cell birth rates were found to be small (i. e. the total cell number could be expected to increase only slightly over the period studied), an approximate value of the daily cell birth rate was calculated (Table 1 ). These latter values were found to be approximately $11 \%$ in the control fetuses and 3\% in the fetuses obtained from manifest diabetic mothers.

\section{Discussion}

In the present study care was taken to optimize the colchicine dose with respect to the degree of mitotic arrest in the tissue studied [14]. It was found, however, in the course of the experiments, that the 20 day fetuses did not tolerate exposure for $4 \mathrm{~h}$ to the drug at the dose optimal for stathmokinetic studies of the islets. Pancreatic and intestinal morphology $3 \mathrm{~h}$ after the colchicine injection appeared normal in comparison with untreated animals [9]. In addition, there was no evidence of a progressive inhibition of the rate of accumulation of mitotic figures, which would have indicated a gradual loss of cell viability. It seems reasonable to assume therefore, that colchicine had little or no adverse effects on the islets during this period.

In stathmokinetic experiments, it is assumed that the drug causing mitotic arrest does not interfere with the progression of the proliferating cells through other
Table 1. Production of new cells by mitotic division in the islets of Langerhans of the offspring of normal and manifest diabetic rat mothers on days 20 and 22 of gestation

\begin{tabular}{llll}
\hline & $\begin{array}{l}\text { Slopes } \\
(\% / \mathrm{h})\end{array}$ & $\begin{array}{l}\text { No. of } \\
\text { observations }\end{array}$ & $\begin{array}{l}\text { Cell birth } \\
\text { rate }(\% / 24 \mathrm{~h})\end{array}$ \\
\hline $\begin{array}{c}\text { Normal } \\
\text { gestational day 20 }\end{array}$ & $0.45 \pm 0.04$ & 36 & 10.8 \\
$\begin{array}{c}\text { Manifest diabetic } \\
\text { gestational day 20 }\end{array}$ & $0.11 \pm 0.05^{\mathrm{a}}$ & 45 & 2.6 \\
$\begin{array}{c}\text { Normal } \\
\text { gestational day 22 }\end{array}$ & $0.46 \pm 0.07$ & 38 & 11.0 \\
$\begin{array}{c}\text { Manifest diabetic } \\
\text { gestational day 22 }\end{array}$ & $0.15 \pm 0.05^{\mathrm{a}}$ & 47 & 3.6 \\
\hline
\end{tabular}

The slope values \pm SEM are those of the corresponding fitted least square regression lines shown in Figs. 1 and 2.

${ }^{\mathrm{a}} p<0.001$; significance of difference between normal and diabetic mothers of the same gestational age

phases of the cell cycle. Inhibition of DNA synthesis by colchicine in the tissues of the fetal rat, without a corresponding effect in the pregnant mother receiving the injection, has however been reported [15]. Such an S phase inhibition of proliferation would decrease the accumulation of mitotic figures if the observation time were longer than the duration of the $\mathrm{G}_{2}$ phase. The latter has previously been estimated in vitro to be $5.5 \mathrm{~h}$ for fetal rat islet cells [26]. The present stathmokinetic curves do not suggest such an inhibition of DNA synthesis, since they are linear throughout the observation period.

The characteristic property of stathmokinetic analyses of rates of cell proliferation is that they provide a true estimation of the proportion of new cells produced by mitotic division rather than increases in tissue mass or comparative indices of proliferation. The present finding of low cell birth rates in the manifest diabetic groups therefore lends strong support to the view that the development and growth of the endocrine pancreas is severely retarded in the fetuses of the diabetic rat mothers used in this and previous studies [9-11]. It should be noted, however, that the present cell birth rates reflect the mitotic activity of all the islet cell types. In fetuses of normal rats the B cells compose some twothirds of the total pancreatic cell volume and this fraction increases only slightly between days 20 and 22 of gestation [13]. It seems reasonable, therefore, to conclude that the cell birth rates observed in the control fetuses mainly reflected the rates of $\mathrm{B}$ cell multiplication. There is still the possibility that the low cell birth rates in manifest diabetic groups could reflect a particularly low proliferation of the non-B cells while the B cell multiplication proceeds at a normal or enhanced rate. This concept, however, appears unlikely in view of the previous finding of a decreased immunostainable $B$ cell mass in these fetuses [9]. Furthermore, these fetuses exhibited a marked decrease in pancreatic insulin content but normal content of glucagon and somatostatin [10]. Thus it is conceivable that the diminished cell birth rates presently demonstrated in the fetuses of manifest diabetic rats reflect a retarded growth rate of the pancreatic $B$ cell. 
The observation in the control fetuses that the islet cell birth rate was approximately $11 \% / 24 \mathrm{~h}$ is consistent with previous observations of relatively low mitotic and autoradiographic indices in the endocrine pancreas of rat fetuses [16-18]. This rate, however, contrasts with the two-to fourfold increase in islet volume and insulin positive cell mass observed between days 20 and 22 of gestation $[9,13,18]$. These comparisons suggest that mechanisms other than mitotic division may also be involved in the rapid increase in B cell mass observed during late pregnancy in the rat, e.g. increase in size of individual islet cells [19] and/or neoformation of islet cells from putative precursors within or outside the islets [20-22]. However, there is no further evidence to support this latter hypothesis.

The present data suggest that the rate of formation of new islet cells in vivo in 22-day fetuses of normal mothers is approximately threefold greater than that observed in vitro after stathmokinetic analyses of islets from 22-day fetuses cultured at a glucose concentration of $2.7 \mathrm{mmol} / 1$ [26]. Although this latter figure simulates the serum glucose concentration of the fetuses in utero [10] the culture medium used had a low amino acid content compared with the high values in fetal rats of this gestational age [23]. Increased amino acid levels markedly stimulate B cell DNA replication [24] and may be even more efficient than glucose in this respect during early development [25]. If the delayed maturation of the pancreatic B cell observed previously in the offspring of manifest diabetic rat mothers $[7,8,12]$ also includes a lack of glucose-stimulated B cell multiplication, this could explain the previously observed reduced B cell mass [9] and the present low rate of $B$ cell division.

Acknowledgements. The authors are indebted to Professor C.Hellerström for criticism and valuable discussions during the preparation of this manuscript. The expert technical assistance of A. Nordin, E. Törnelius, A.-B. Andersson and C. Bittkowski is gratefully acknowledged. This work was supported by grants from the Medical Faculty of the University of Uppsala, the Swedish Diabetes Association, the Nordic Insulin Fund, The Novo Company, the Expressen Prenatal Research Foundation, the Swedish Society for Medical Sciences, syskonen Svenssons minnesfond, stiftelsen Clas Groschinskys minnesfond and the Swedish Medical Research Council (grants No 12X-109 and 12X-2297).

\section{References}

1. Pedersen J (1954) Weight and length at birth of infants of diabetic mothers. Acta Endocrinol 16:330-342

2. Wellman KF, Volk BW (1977) The islets of infants of diabetic mothers. In: Volk BW, Wellman KF (eds) The diabetic pancreas. Plenum Press, New York, pp 365-380

3. Angervall L (1959) Alloxan diabetes and pregnancy in the rat. Acta Endocrinol 31 (Suppl 44): 1-86

4. Solomon F (1959) Embryomegaly and increased fetal mortality in pregnant rats with mild alloxan diabetes. Diabetes $8: 45-50$

5. Kim JM, Runge W, Wells LJ, Lazarow A (1960) Pancreatic islets and blood sugars in prenatal and postnatal offspring from diabetic rats: beta granulation and glycogen infiltration. Anat Rec 137: $239-260$

6. Pitkin RM, Van Orden DE (1974) Fetal effects of maternal streptozotocin-diabetes. Endocrinology 94: 1247-1253
7. Aerts L, Van Assche FA (1977) Rat foetal endocrine pancreas in experimental diabetes. J Endocrinol 73: 339-346

8. Kervran A, Guillaume M, Jost A (1978) The endocrine pancreas of the fetus from diabetic pregnant rat. Diabetologia 15: 387-393

9. Eriksson U, Swenne I (1982) Diabetes in pregnancy: growth of the foetal B-cell in the rat. Biol Neonate (in press)

10. Eriksson U, Andersson A, Efendić S, Elde R, Hellerström C (1980) Diabetes in pregnancy: effects on the foetal and newborn rat with particular regard to body weight, serum insulin concentration and pancreatic contents of insulin, glucagon and somatostatin. Acta Endocrinol 94: 354-364

11. Eriksson U, Hellerström C, Andersson A (1981) Diabetes in pregnancy: effects on the maturation of (pro)insulin biosynthesis in fetal and neonatal rat islets. Diab Metab 7: 243-249

12. Eriksson U (1981) Diabetes in pregnancy: a study of complications in the offspring of the rat. Thesis. Acta Universitatis Upsaliensis 398: $1-35$

13. McEvoy RC, Madson KL (1980) Pancreatic insulin-, glucagon-, and somatostatin-positive cell populations during the perinatal development of the rat. I. Morphometric quantitation. Biol Neonate 38: 248-254

14. Wright NA, Appleton DR (1980) The metaphase arrest technique. A critical review. Cell Tissue Kinet 13: 643-663

15. Williams JPG (1973) The embryospecific action of stathmokinetic agents. In: Balls M, Billett FS (eds) The cell cycle in development and differentiation. Cambridge University Press, pp 331-335

16. Frye BE (1957) The differentiation of the endocrine pancreas in fetuses of alloxan diabetic and insulin-treated rats. J Morphol 101: 325-357

17. Blum B, Heggestad C, Lazarow A (1963) DNA synthesis in pancreatic islet tissue from fetal and young postnatal rats. Anat Rec 145: $309-310$

18. Freie HMP, Pasma A, Bouman PR (1975) Quantitative analysis of pancreatic islet development and insulin storage in the foetal and newborn rat. Acta Endocrinol 80:657-666

19. Winick M, Noble A (1965) Quantitative changes in DNA, RNA and protein during prenatal and postnatal growth in the rat. Develop Biol 12: 451-466

20. Bunnag SC, Warner NE, Bunnag S (1967) Effect of alloxan on the mouse pancreas during and after recovery from diabetes. Diabetes $16: 83-89$

21. Melmed RN, Benitez CJ, Holt SJ (1972) Intermediate cells of the pancreas. I. Ultrastructural characterization. J Cell Sci 11: 449-475

22. Pictet R, Rutter WJ (1972) Development of the embryonic endocrine pancreas. In: Steiner DF, Freinkel N (eds) Handbook of physiology, Sect 7, vol 1. American Physiological Society, Baltimore, pp 25-66

23. Girard JR, Cuendet GS, Marliss EB, Kervran A, Rieutort M, Assan R (1973) Fuels, hormones, and liver metabolism at term and during the early postnatal period in the rat. $J$ Clin Invest 52: $3190-3200$

24. Swenne I, Bone AJ, Howell SL, Hellerström C (1980) Effects of glucose and amino acids on the biosynthesis of DNA and insulin in fetal rat islets maintained in tissue culture. Diabetes 29: 686-692

25. Gasparo M de, Milner GR, Norris PD, Milner RDG (1978) Effect of glucose and amino acids on foetal rat pancreatic growth and insulin secretion in vitro. J Endocrinol $77: 241-248$

26. Swenne I (1982) Role of glucose in the in vitro regulation of cell cycle kinetics and proliferation in fetal pancreatic B-cells. Diabetes $31: 754-760$

Received: 1 March 1982

and in revised form: 22 June 1982

Dr. I. Swenne

Department of Medical Cell Biology

Biomedicum, P.O. Box 571

S-75123 Uppsala, Sweden 